\title{
Analysis of $\mathrm{Ni} / \mathrm{Cu}$ Metallization to Investigate an Adhesive Front Contact for Crystalline-Silicon Solar Cells
}

\author{
Sang Hee Lee, Atteq ur Rehman, Eun Gu Shin, Doo Won Lee, and Soo Hong Lee* \\ Green Strategic Energy Research Institute, Department of Electronics Engineering, Sejong University, \\ Seoul 143-747, Korea
}

(Received January 5, 2015 : revised February 11, 2015 : accepted February 24, 2015)

\begin{abstract}
Developing a metallization that has low cost and high efficiency is essential in solar-cell industries, to replace expensive silver-based metallization. $\mathrm{Ni} / \mathrm{Cu}$ two-step metallization is one way to reduce the cost of solar cells, because the price of copper is about 100 times less than that of silver. Alkaline electroless plating was used for depositing nickel seed layers on the front electrode area. Prior to the nickel deposition process, $2 \%$ HF solution was used to remove native oxide, which disturbs uniform nickel plating. In the subsequent step, a nickel sintering process was carried out in $\mathrm{N}_{2}$ gas atmosphere; however, copper was plated by light-induced plating (LIP). Plated nickel has different properties under different bath conditions because nickel electroless plating is a completely chemical process. In this paper, plating bath conditions such as $\mathrm{pH}$ and temperature were varied, and the metal layer's structure was analyzed to investigate the adhesion of $\mathrm{Ni} / \mathrm{Cu}$ metallization. Average adhesion values in the range of $0.2-0.49 \mathrm{~N} / \mathrm{mm}$ were achieved for samples with no nickel sintering process.
\end{abstract}

Keywords: Adhesion, Nickel electro-less plating, Sintering, HF solution, Copper LIP

OCIS codes : (040.5350) Photovoltaic; (130.5990) Semiconductors; (160.5140) Photoconductive materials; (160.6000) Semiconductor materials; (350.6050) Solar energy

\section{INTRODUCTION}

For front contacts, the Ag-paste screen-printing technique has occupied most of the photovoltaic (PV) industry because the process is simple and easily automated, since it was first applied to solar cells in 1975 [1]. However, because $\mathrm{Ag}$ is expensive and has disadvantages such as low aspect ratio and high contact resistance, new metallization techniques have been researched [2]. For a new front contact, low contact resistance and good adhesion with an inexpensive material is required to make better-performing solar cells. To meet these requirements, $\mathrm{Ni} / \mathrm{Cu}$ plating has been researched as a promising technique [2-4]. A nickel layer between copper and silicon acts as a good diffusion barrier, and also form nickel silicide, which yields low contact resistance and good adhesion after sintering [5].

Electroless nickel plating is a suitable method for solar cells after selective laser ablation of $\mathrm{SiN}_{\mathrm{x}}$, as nickel can be plated by a self-aligned process on the opened narrow area
[2]. Because electroless plating is a completely chemical process, bath conditions such as $\mathrm{pH}$, temperature, and concentration can make a difference in the deposition properties [3]. For the deposition of metal, adhesive and surface coverage are significant characteristics. To meet the needs for these characteristics, the cluster size of deposited nickel is an important factor, and it depends on bath temperature and $\mathrm{pH}$ [6].

Above the nickel barrier layer, copper is deposited by lightinduced electroplating (LIP) as the front contact thickening. LIP uses photocurrent, which is generated under light, and this has some advantages. A simplified process is possible because there is no need to contact the front side. Also, LIP can produce homogeneous plating compared to electroplating, because the front contact area has the same electrical potential over the whole area [7].

In this study, the $\mathrm{pH}$ and temperature of a nickel electroless plating bath are varied to investigate their influence on the adhesion of a $\mathrm{Ni} / \mathrm{Cu}$ front contact.

\footnotetext{
*Corresponding author: shl@sejong.ac.kr

Color versions of one or more of the figures in this paper are available online.
} 


\section{EXPERIMENTAL DETAILS}

Samples were prepared on a $\mathrm{POCl}_{3}$ diffused $(70 \mathrm{ohm} / \mathrm{sq}$ ) and pyramid textured $p$-type silicon (100) wafer to analyze cluster size and thickness of the deposited nickel. To measure the adhesion of the $\mathrm{Ni} / \mathrm{Cu}$ contact, the $\mathrm{SiN}_{\mathrm{x}}$ antireflection layer was removed by selective laser ablation, and then an $\mathrm{Al}$ is screen printed and fired to form the back contact. Last, the $\mathrm{Ni} / \mathrm{Cu}$ front contact was formed by plating, as depicted in the FE-SEM images in Fig. 1 (a) and (b), showing respectively the laser-ablated area before and after the metallization process. The thickness and surface of deposited nickel was measured using a field-emission scanning electron microscope (FE-SEM, JSM-7100F), and the adhesion of the $\mathrm{Ni} / \mathrm{Cu}$ contact was measured using a universal testing machine (UTM, H5KT) with $90^{\circ}$ angle.

\subsection{Nickel Electroless Plating}

Ni plating was carried out by submerging the samples in an alkaline solution. Before nickel electroless plating, native oxide on the silicon area was etched using a $2 \% \mathrm{HF}$ solution. Nickel chloride $\left(\mathrm{NiCl}_{2} \cdot 6 \mathrm{H}_{2} \mathrm{O}\right)$ was used as the main source. Each source was used for its own purpose: sodium hypophosphite $\left(\mathrm{NaH}_{2} \mathrm{PO}_{2} \cdot \mathrm{H}_{2} \mathrm{O}\right)$ as a reducing agent, triammonium citrate $\left(\left(\mathrm{NH}_{4}\right)_{3} \mathrm{C}_{6} \mathrm{H}_{5} \mathrm{O}_{7}\right)$ as a complex agent, and ammonium chloride $\left(\mathrm{NH}_{4} \mathrm{Cl}\right)$ as a buffer agent to stabilize the $\mathrm{pH}$ of the solution. Also, ammonium hydroxide $\left(\mathrm{NH}_{4} \mathrm{OH}\right)$ was used to control the $\mathrm{pH}$ of the solution. The chemical reactions of nickel electroless plating are as follows [8-11]:

$$
\begin{aligned}
& \mathrm{H}_{2} \mathrm{PO}_{2}^{-}+\mathrm{H}_{2} \mathrm{O} \rightarrow \mathrm{HPO}_{3}^{2-}+2 \mathrm{H}^{+}+\mathrm{H}^{-} \\
& 2 \mathrm{H}+\mathrm{Ni}^{2+} \rightarrow \mathrm{Ni}+\mathrm{H}_{2}
\end{aligned}
$$

$$
2 \mathrm{H}_{2} \mathrm{PO}_{2}^{-}+2 \mathrm{H}_{2} \mathrm{O}+\mathrm{Ni}^{2+} \rightarrow \mathrm{Ni}+\mathrm{H}_{2}+4 \mathrm{H}^{+}+2 \mathrm{HPO}_{3}^{2-}
$$

The net reaction in Eq. (3) is obtained by adding Eq. (1) and (2) for reactions that occur concurrently. The $\mathrm{pH}$ of the bath was varied as $8,8.5$, and 9 at $60{ }^{\circ} \mathrm{C}$; temperature was varied as 60,70 , and $80{ }^{\circ} \mathrm{C}$ in a bath of $\mathrm{pH} 8$. To investigate the effect of sintering on contact adhesion, another nickel-plated sample with $\mathrm{pH} 8$ was plated at 80 ${ }^{\circ} \mathrm{C}$. The sintering process was conducted in ambient $\mathrm{N}_{2}$ gas for 90 seconds at $300{ }^{\circ} \mathrm{C}$ in a conventional tube furnace, as nickel silicide $\left(\mathrm{NiSi}_{\mathrm{x}}\right)$ can be formed between 200 and $900{ }^{\circ} \mathrm{C}[12]$.

\subsection{Copper Plating by LIP}

$\mathrm{Cu}$ plating was conducted by light-induced plating. The main source of $\mathrm{Cu}$ is copper sulfate $\left(\mathrm{CuSO}_{4} \cdot 5 \mathrm{H}_{2} \mathrm{O}\right)$, which produces copper ions $\left(\mathrm{Cu}^{2+}\right)$ in the bath. High copper concentration produces high current density in the solution. However, if copper from the anode contributes to exceed the solubility limit of $240 \mathrm{~g} / \mathrm{L}$, copper sulfate recrystallizes on the plating bath. Also, sulfuric acid $\left(\mathrm{H}_{2} \mathrm{SO}_{4}\right)$ was added to the solution to enhance conductivity [13].

$$
\begin{aligned}
& \mathrm{Cu}+2 \mathrm{e}^{+} \rightarrow \mathrm{Cu}^{2+} \\
& \mathrm{Cu}+2 \mathrm{e}^{+} \rightarrow \mathrm{Cu}^{2+} \\
& \mathrm{H}_{2} \mathrm{SO}_{4} \rightarrow 2 \mathrm{H}^{+}+\mathrm{SO}_{4}^{2-} \\
& \mathrm{Cu}^{2+}+2 \mathrm{e}^{-} \rightarrow \mathrm{Cu}
\end{aligned}
$$

The above equations show the reaction at the anode (3), in the solution (4), and at the cathode (5). Figure 2 shows the $\mathrm{Cu}$ LIP process.

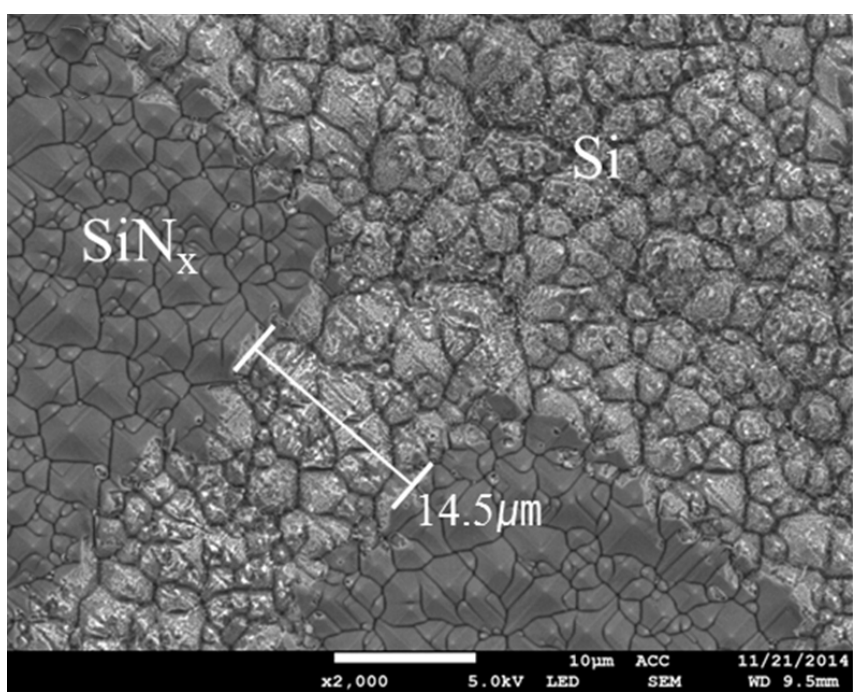

(a)

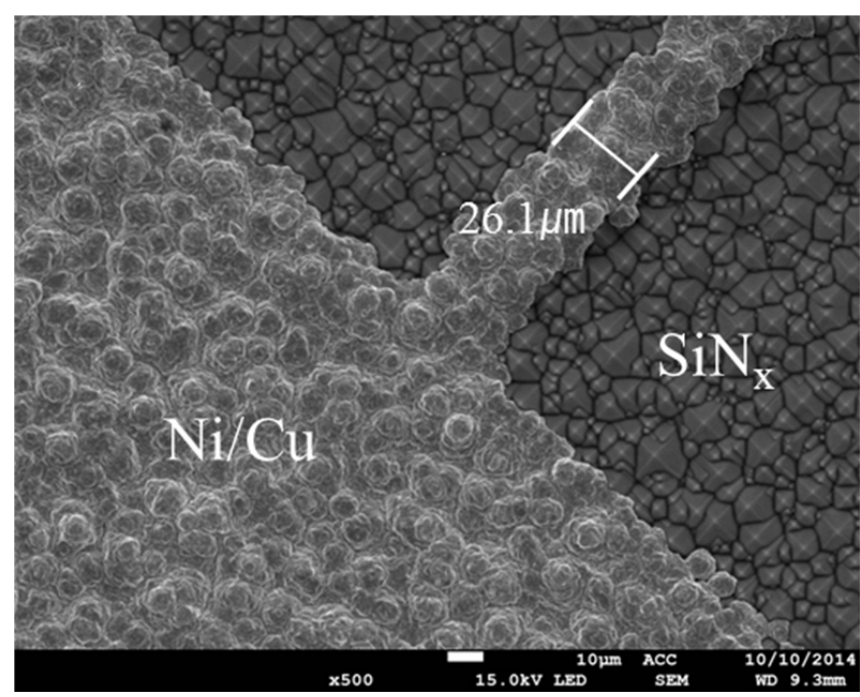

(b)

FIG. 1. FE-SEM front views of laser-ablated area (a) before and (b) after $\mathrm{Ni} / \mathrm{Cu}$ plating. 


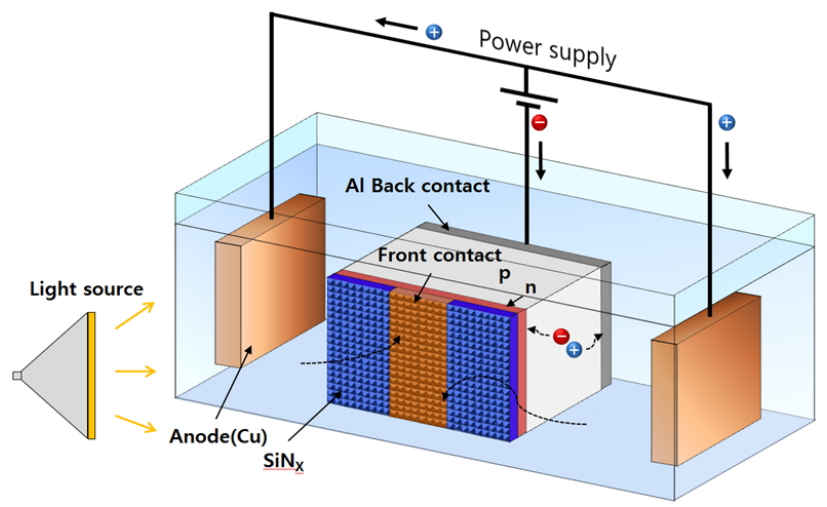

FIG. 2. Schematic diagram of the light induced plating (LIP) process.

\section{Temperature variation}

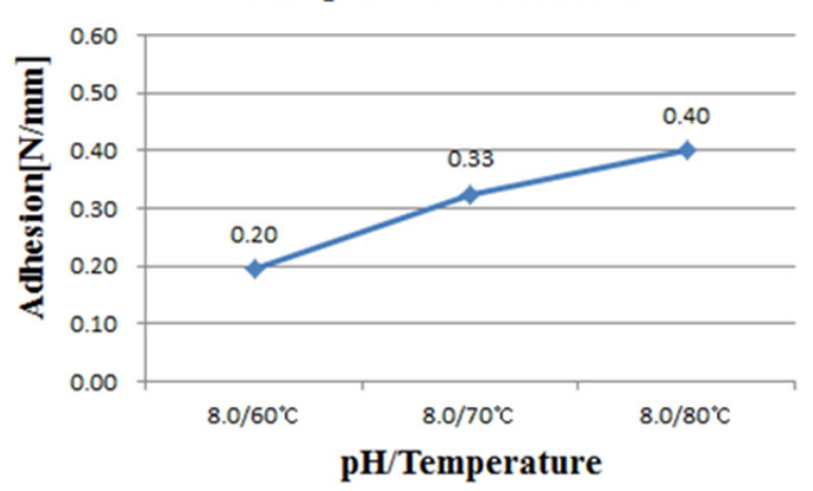

(a)

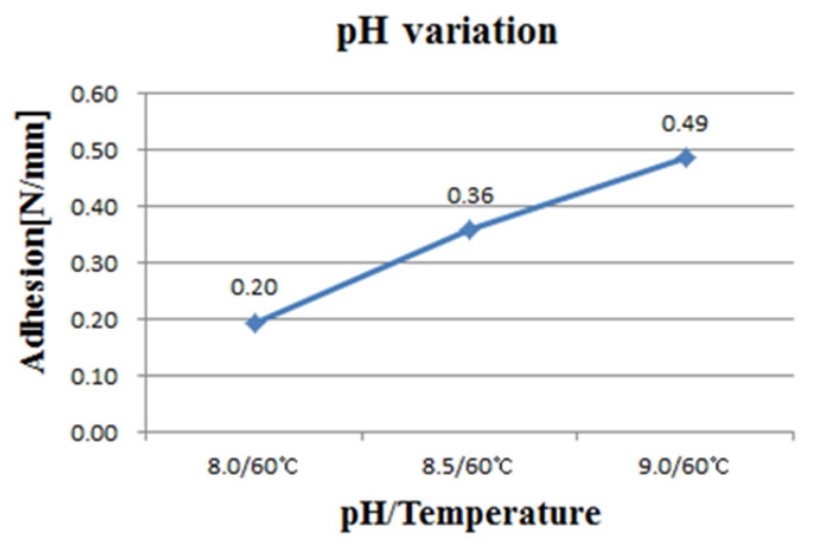

(b)

FIG. 3. Average peel force test results for a $\mathrm{Ni} / \mathrm{Cu}$ front contact with variation in temperature (a) and $\mathrm{pH}(\mathrm{b})$.

\section{RESULTS AND DISCUSSION}

The peel force test was carried out using a UTM (H5KT) to see the influence of bath conditions on $\mathrm{Ni} / \mathrm{Cu}$ contact adhesion. The measured nickel thickness was in the range of 400-500 nm, while the copper layer was about $4 \mu \mathrm{m}$ thick. The average adhesion was measured for a bus bar of length
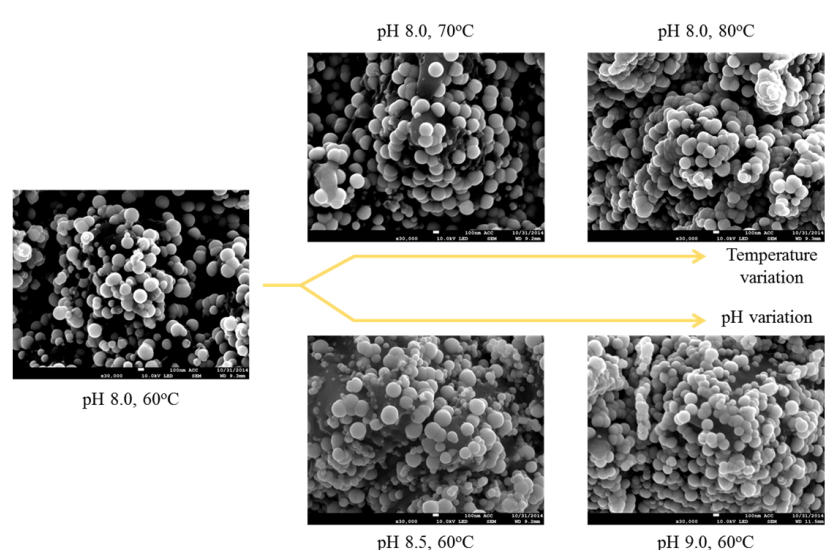

$\mathrm{pH} 9.0,60^{\circ} \mathrm{C}$

FIG. 4. FE-SEM front views of deposited nickel clusters at various $\mathrm{pH}$ and temperature values.

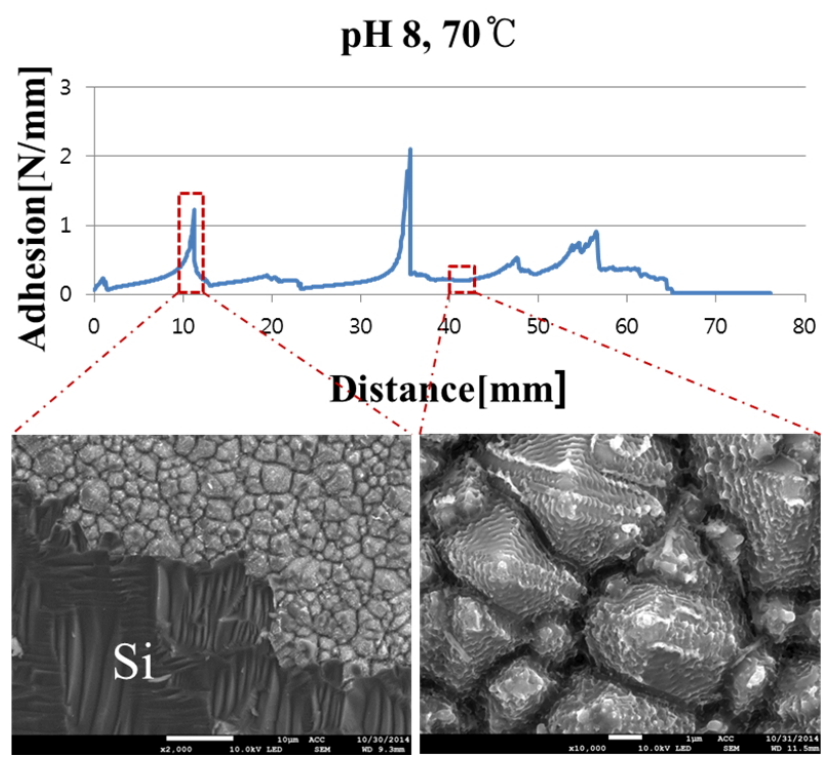

FIG. 5. Peel force test results with $1.5 \mathrm{~mm}$ bus bar width (top), along with FE-SEM top views of silicon bus bar area with high adhesion (left) and low adhesion (right) areas.

$64 \mathrm{~mm}$ and width $1.5 \mathrm{~mm}$, for each $\mathrm{pH}$ and temperature value. The average adhesion values of non-sintered samples are plotted in Fig. 3, varying from 0.2 to $0.49 \mathrm{~N} / \mathrm{mm}$. The maximum adhesion strength value of $2.18 \mathrm{~N} / \mathrm{mm}$ was recorded for $\mathrm{pH} 9$ at $60{ }^{\circ} \mathrm{C}$ (even with no sintering process).

To study the dependence of nickel cluster size on various bath conditions, nickel layers were deposited for 2 minutes. Figure 4 shows FE-SEM top views of the nickel surface for various bath conditions (temperature $60-80{ }^{\circ} \mathrm{C}, \mathrm{pH} 8-9$ ). A very slight change in cluster size was observed (170-200 $\mathrm{nm}$ ) for each process condition. However, measuring the distinctive cluster sizes at each condition and identifying the expected variation in sizes were quite difficult due to the inconsistent cluster sizes, which depended on location: cluster size was different on a pyramid than in a valley.

The sample that was nickel-plated at $\mathrm{pH} 8$ and $70{ }^{\circ} \mathrm{C}$ 


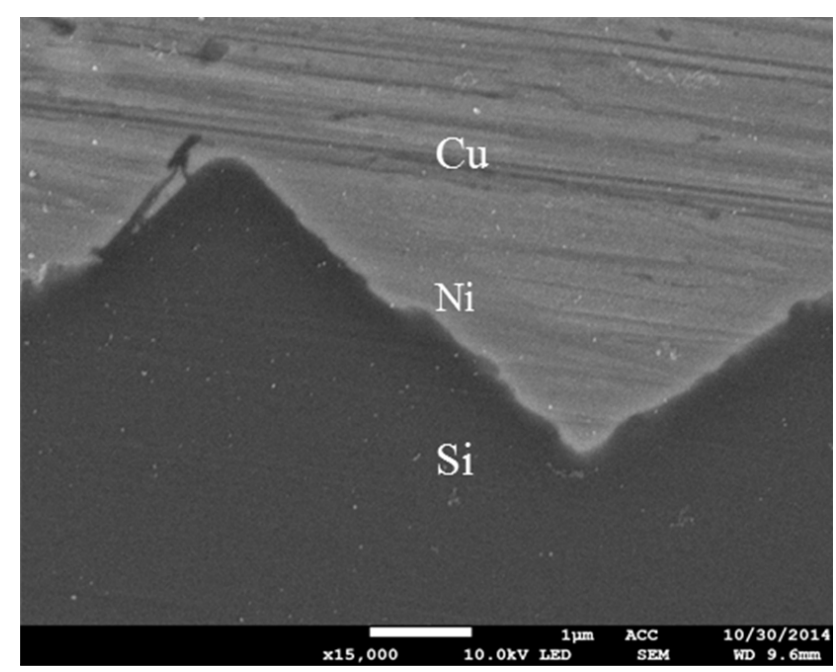

(a)

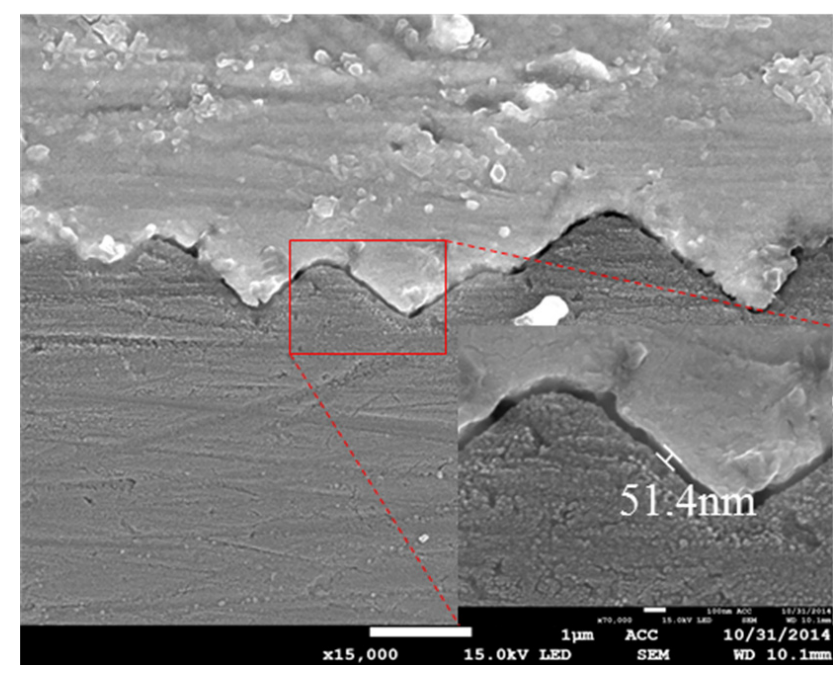

(b)

FIG. 6. Polished FE-SEM cross-sectional images for the sample with high peel force test results with (a) no $\mathrm{NiSi}_{\mathrm{x}}$ etching and (b) $\mathrm{NiSi}_{\mathrm{x}}$ etching.

was further investigated by comparing its adhesion result with its FE-SEM visual image. In Fig. 5, the peel force test results, along with FE-SEM top views of the silicon bus bar area, for the conducted peel force test sample are shown. It can be observed very clearly that the silicon material with high adhesion force is peeled off from the substrate along the $\mathrm{Ni} / \mathrm{Cu}$ contact, while it is not affected in a low adhesion area. The adhesion strength difference was observed 6 to 10 times using areas with low and high adhesion results.

The non-sintered samples were further studied to confirm the formation of nickel silicide $\left(\mathrm{NiSi}_{\mathrm{x}}\right)$ at the nickel-silicon interface. Selective nickel silicide etching was performed to check for a $\mathrm{NiSi}_{\mathrm{x}}$ layer in the nickel-silicon interface using a solution containing $5 \% \mathrm{HF}$ and $3 \% \mathrm{H}_{2} \mathrm{O}_{2}$. The admixed solution of $\mathrm{HF}$ and $\mathrm{H}_{2} \mathrm{O}_{2}$ has already been reported to etch a $\mathrm{NiSi}_{\mathrm{x}}$ layer selectively [14]. The images in Fig. 6 (a) and

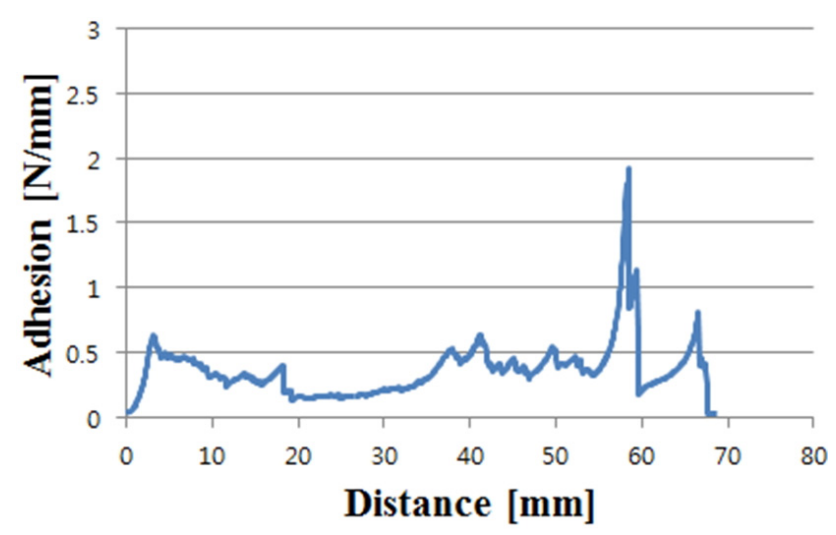

(a)

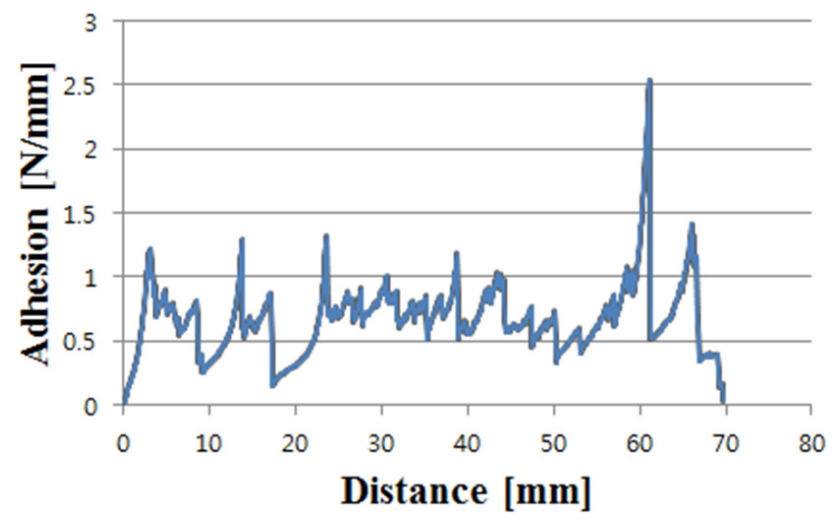

(b)

FIG. 7. Peel force test results with $1.5 \mathrm{~mm}$ bus bar width for (a) non-sintered sample and (b) sample sintered at $300{ }^{\circ} \mathrm{C}$ with bath at $\mathrm{pH} 8$ and $80{ }^{\circ} \mathrm{C}$.

TABLE 1. Measured peel force test result of non-sintered sample and sintered sample

\begin{tabular}{c|c|c}
\hline \hline Process & $\begin{array}{c}\text { Average adhesion } \\
{[\mathrm{N} / \mathrm{mm}]}\end{array}$ & $\begin{array}{c}\text { Maximum adhesion } \\
{[\mathrm{N} / \mathrm{mm}]}\end{array}$ \\
\hline No sintering & 0.36 & 1.92 \\
\hline Sintering & 0.67 & 2.54 \\
\hline
\end{tabular}

(b) show the FE-SEM cross sections of samples with no $\mathrm{NiSi}_{\mathrm{x}}$ etching and $\mathrm{NiSi}_{\mathrm{x}}$ etched samples respectively. The cross section in Fig. 6 (b) clearly shows that a NiSi $\mathrm{x}_{\mathrm{x}}$ layer about 50 to $100 \mathrm{~nm}$ in thickness was etched under the nickel layer, confirming the presence of a NiSi $i_{x}$ layer at the nickelsilicon interface. A possible reason for the presence of a $\mathrm{NiSi}_{\mathrm{x}}$ layer, even with no sintering process, is the ribbon soldering process conducted at $390{ }^{\circ} \mathrm{C}$, as $\mathrm{NiSi}_{\mathrm{x}}$ forms between 200 and $900{ }^{\circ} \mathrm{C}$ [2].

To see the influence of $\mathrm{NiSi}_{\mathrm{x}}$ on the $\mathrm{Ni} / \mathrm{Cu}$ contact adhesion, for the nickel-plated sample formed at $\mathrm{pH} 8$ and $80{ }^{\circ} \mathrm{C}$ and sintered at $300{ }^{\circ} \mathrm{C}$ for 90 seconds, the peel force test was conducted and is shown in Fig. 7 (b). Figure 7 shows peel force test results for sintered and non-sintered samples. It can be seen that the overall adhesion values have increased 
for the sintered sample (Fig. 7 (b)), compared to the nonsintered sample (Fig. 7 (a)). The average adhesion value was improved about 1.8 times and the maximum adhesion strength of about $2.54 \mathrm{~N} / \mathrm{mm}$ was recorded. The comparison of sintered and non-sintered samples using peel force test results is summarized in Table 1.

\section{CONCLUSION}

$\mathrm{Ni} / \mathrm{Cu}$ metal stacks were successfully deposited on laser-ablated ARC-opened silicon surfaces to form front electrodes for silicon solar cells. This experiment was carried out to study the effect of nickel cluster size on the adhesion of a Ni/Cu contact to a silicon surface. An average adhesion force of 0.2-0.49 N/mm, with a maximum value of $2.18 \mathrm{~N} / \mathrm{mm}$, was achieved without sintering. A slight change in cluster size, up to $30 \mathrm{~nm}$, was detected for all values of $\mathrm{pH}$ and temperature. The high adhesion force of $2.18 \mathrm{~N} / \mathrm{mm}$ is due to the ribbon soldering process for the peel force test. The presence of $\mathrm{NiSi}_{\mathrm{x}}$ layers was confirmed by a selective $\mathrm{NiSi}_{\mathrm{x}}$ etching process. By including the Ni sintering process, the average adhesion value was improved about 1.8 times, with a maximum value of about $2.54 \mathrm{~N} / \mathrm{mm}$ being achieved. The sample with higher adhesion suggests that the formation of the $\mathrm{NiSi}_{\mathrm{x}}$ layer is more critical than the Ni cluster size, varied by the bath conditions, for creating an adhesive $\mathrm{Ni} / \mathrm{Cu}$ front contact on the silicon surface.

\section{ACKNOWLEDGMENT}

This work was supported by the New \& Renewable Energy Core Technology Program of the Korea Institute of Energy Technology Evaluation and Planning (KETEP) granted financial resource from the Ministry of Trade, Industry \& Energy, Republic of Korea (No. 20133010011780)

\section{REFERENCES}

1. E. Ralph, "Recent advancements in low cost solar cell processing," in Proc. 11th Photovoltaic Specialists Conference (Scottsdale, AZ, USA, 1975), vol. 1, p. 315.
2. A. Rehman and S. H. Lee, "Review of the potential of the $\mathrm{Ni} / \mathrm{Cu}$ plating technique for crystalline silicon solar cells," Materials 7, 1318-1341 (2014).

3. E. J. Lee, D. S. Kim, and S. H. Lee, "Ni/Cu metallization for low-cost high-efficiency PERC cells," Solar Energy Materials and Solar Cells 74, 65-70 (2002).

4. S. Glunz, M. Aleman, J. Bartsch, N. Bay, K. Bayer, R. Bergander, A. Filipovic, S. Greil, A. Grohe, and M. Horteis, "Progress in advanced metallization technology at Fraunhofer ISE," in Proc. $33^{\text {rd }}$ IEEE Photovoltaic Specialists Conference (Manchester Grand Hyatt San Diego, San Diego, CA, USA, 2008).

5. D. K. Schroder and D. L. Meier, "Solar cell contact resistance-A review," IEEE Transactions on Electron Devices 31, 637-647 (1984).

6. G. Hu, H. Wu, and F. Yang, "Direct electroless nickel plating on silicon surface," Chinese Science Bulletin 49, 2363-2367 (2004).

7. A. Mette, "New concepts for front side metallization of industrial silicon solar cells," Dissertation Thesis, University of Freiburg, Germany (2007).

8. J. H. Guo and J. E. Cotter, "Metallization improvement on fabrication of interdigitated backside and double sided buried contact solar cells," Solar Energy Materials and Solar Cells 86, 485-498 (2005).

9. J. D. Lee, H. Y. Kwon, and S. H. Lee, "Analysis of front metal contact for plated $\mathrm{Ni} / \mathrm{Cu}$ silicon solar cell," Electronic Materials Letters 7, 349-352 (2011).

10. P. Vitanov, N. Tyutyundzhiev, P. Stefchev, and B. Karamfilov, "Low cost multilayer metallization system for silicon solar cells," Solar Energy Materials And Solar Cells 44, 471-484 (1996).

11. H. Hsu, C. Tsai, C. Lee, and H. Wu, "Mechanism of immersion deposition of Ni-P films on $\mathrm{Si}(100)$ in an aqueous alkaline solution containing sodium hypophosphite," Thin Solid Films 517, 4786-4791 (2009).

12. E. K. Lee, D. C. Lim, K. H. Lee, and J.-H. Lim, "Selfaligned Ni-P ohmic contact scheme for silicon solar cells by electroless deposition," Electronic Materials Letters 8, 391-395 (2012).

13. W. J. Oh and S. H. Lee, "Investigation of selective emitter in single step diffusion process for plated $\mathrm{Ni} / \mathrm{Cu}$ metallization crystalline silicon solar cells," Current Applied Physics 13, S186-S189 (2013).

14. B. Kim and H. S. Seo, "Etchant for nickel silicide," U.S. Patents Application 11/095, 484, April 1 (2005). 